Ilmu Pertanian (Agricultural Science)

Vol. 3 No. 1 April, $2018: 36-45$

Available online at http://journal.ugm.ac.id/jip

DOI: doi.org/10.22146/ipas.39621

ILMU PERTANIAN
(AGRICULTURAL SCIENCE)

\title{
The effect of priming duration with salicylic acid under salinity stress on growth and leaf anatomy of sweet corn (Zea mays $\mathrm{L} ._{\text {. }}$ **
}

\author{
Krisnanda Surya Dharma ${ }^{1}$ and Maryani2* \\ ${ }^{1}$ Undergraduate Alumnus Faculty of Biology, Universitas Gadjah Mada \\ ${ }^{2}$ Laboratory of Plant Structure and Development, Faculty of Biology, Universitas Gadjah Mada \\ Jl. Teknika Selatan, Sekip Utara, Yogyakarta 55281 \\ *Corresponding email: mmyani@ugm.ac.id \\ Received: 12 $2^{\text {nd }}$ October 2018; Revised: 20 ${ }^{\text {th }}$ December 2018; Accepted: $20^{\text {th }}$ December 2018
}

\begin{abstract}
Salinity stress is known for adverse effect on plants. Priming with salicylic acid was able to improve plant performance under salinity stress. This study aimed to determine the effect of priming duration with salicylic acid on growth, leaf anatomy and the optimal priming duration for sweet corn seedlings (Zea mays L.) under salinity stress. The experiment was based on Completely Randomized Design with two factors and five replications. The first factor was priming duration with salicylic acid $(2 \mathrm{mM})$ with four different durations $(0,12,18$ and $24 \mathrm{~h})$. The second factor was the level of salinity $(\mathrm{NaCl} 0 \%$ and $3 \%)$. Parameters observed were germination percentage, plant height, root length, fresh weight, dry weight, chlorophyll content, leaf proline content, leaf anatomy and stomatal density. Data were analyzed with t-test, ANOVA and followed by Duncan's test at 95\% confidence level. The results showed that 18-h priming duration observed as the highest germination percentage which was $7 \%$ higher than control. Priming for $24 \mathrm{~h}$ showed phytotoxic effect for sweet corn on the germination phase by reducing the percentage of germination. The application of salicylic acid mitigated the toxic effects of $\mathrm{NaCl}$ stress on maize seedlings and considerably improved root and shoot growth, photosynthetic pigments, fresh weight, dry weight, proline content, and stomatal density, as well as could maintaining the leaf anatomy. The optimal priming duration with salicylic acid for sweet corn seedlings under $3 \%$ salinity was $18 \mathrm{~h}$.
\end{abstract}

Keywords: Sweet corn; salicylic acid; salinity; priming duration.

\section{INTRODUCTION}

Seed priming is one of the physiological approaches that can increase the resistance of plants in stress conditions (Nawaz et al.2013). Priming techniques are being used to improve seed germination under both optimal and adverse condition (Jisha et al., 2013). After priming, seeds can be dried and stored for long periods and the growth of seedlingswill be faster and uniform (Imran, 2012).

Hormonal priming is a priming treatment with phytohormones, such as gibberellin, kinetin or salicylic acid(Nawaz et al.2013). Salicylic acid is a phenolic compound that plays a role in plant defense mechanisms against both biotic and abiotic stress, including salinity stress (Zahra et al., 2010). Salicylic acid can prevent the release of $\mathrm{K}+$ ions and the membrane potential recovery that impacts on the increase of plant tolerance to salinity stress (Jayakannam et al., 2013). In Torreya grandis, salicylic acid can increase chlorophyll and biomass (Li et al., 2014). Together with gibberellin, salicylic acid elevated levels of chlorophyll $a$ and $b$ on Trigonella foenum-graecoum when subjected to salt stress (Farahmandfar et al., 2013). The success of hormonal priming itself is influenced by a number of factors such as duration, concentration and type of hormone given (Sedghiet al., 2014).

Priming with salicylic acid in salinity-treated maize significantly increased dry weight, leaf area, leaf number and stem height with optimum salicylic acid concentration was $2 \mathrm{mM}$ (Zadehbagheri, 2014). Salicylic acid can also induce specific changes in leaf anatomy (Khanet al., 2013). Maize varieties and salinity level differences also affect the tolerance level of the plant to the saline field. For example, a lower initial salinity treatment may increase corn tolerance in 
the vegetative phase when subsequent salinity conditions are increased (Suwignyo et al., 2010).

In Indonesia, projected demand for sweet corn in 2010-2050 tends to increase by $0.65 \%$ per year based on population growth, food preferences, income, price changes, arable land areas and diversification trends in the community (Sudaryanto, 2010). With the increasing transition of agricultural land into residential and industrial areas, causing the area of agriculture to decline. To increase agricultural land, marginal areas that usually have a high salt content, can be an alternative. The soil called saline contains excess salt which generally inhibit the growth of various nontolerant species to salinity (Dachlan et al., 2013). Salinity is one of the obstacles of sweet corn cultivation in Indonesia (Palungkun and Asiani, 2004).

The anatomical structure of the leaves can also undergo changes when subjected to stress and induction of certain hormones. The thickness of the adaxial and abaxial epidermis of maize leaves treated with salinity was thinner than that of controls or plants given salicylic acid (Carcamo et al., 2012). The others anatomical structure changes included Kranz anatomy and mesophyll cell. Salicylic acid also has inhibitory effect on the entry of $\mathrm{Na}^{+}$and $\mathrm{Cl}^{-}$ions at the membrane transport level so that this hormone is responsible for the anatomical changes of plants (Romero-Arandaet al., 2001). The ionic competition between salicylic acid with $\mathrm{Na}^{+}$and $\mathrm{Cl}^{-}$will prevent ionic phytotoxicity so that the tissue in the leaves can still thrive under salinity. Salinity stress increased stomata number in maize leaves (Carcamo et al., 2012). Meanwhile, the reduction of stomatal density and its conductance in tomato leaves resulting from a decrease in plant transpiration rates during salt stress (Romero-Aranda et al., 2001).

The purpose of this study was to evaluate the effect of priming duration with salicylic acid on leaf anatomicall structure and sweet corn plant growth (Zea mays L.) and to determine the optimal priming duration for salted maize (Zea mays L.) maize.

\section{MATERIALS AND METHODS}

The research was conducted in February-May 2017 at Greenhouse, Plant Structure and Development Laboratory, and in Plant Physiology Laboratory, Faculty of Biology UGM, Yogyakarta.

\section{Experiment design}

Experiment used Completely Randomized Design (CRD) with two factors. The first factor was priming duration with $2 \mathrm{mM}$ salicylic acid (Zadehbagheri,
$2014)$ with for different priming time ( $0 \mathrm{~h}(\mathrm{P} 0), 12 \mathrm{~h}$ (P1), $18 \mathrm{~h}$ (P2) and $24 \mathrm{~h}$ (P3) (Arif et al., 2010). The second factor was $\mathrm{NaCl}(0 \%=\mathrm{K} 0$ and $3 \%=\mathrm{K} 1)$. The $3 \%$ was $\mathrm{NaCl}$ able to inhibit maize germination up to $50 \%$ (Zadehbagheri, 2014).

\section{Germination and seedling growth}

Sweet corn seeds were soaked in $2 \mathrm{mM}$ salicylic acid solution each for $0,12,18$ and $24 \mathrm{~h}$. The weight ratio of seeds per volume of salicylic acid solution during submersion was 1: 5 (gmL-1) (Mukhtar et al., 2013). After each priming treatment, the seeds were rinsed 3 times with aquadest and dried for 1 day at room temperature $\left(27^{\circ} \mathrm{C}\right)$ (Herlina and Aziz, 2016). Seeds with priming treatment were planted on polybags with size $15 \mathrm{~cm} \times 7.5 \mathrm{~cm}$ filled with planting medium in the form of husk: compost (2: 1) with a depth of $1 \mathrm{~cm}$. Watering with $3 \% \mathrm{NaCl}$ solution is done on day 0 and every seven days, while the control treatment is doused with water (Adillah, 2016). The watering volume is adjusted to the field capacity for growing media. During the period of one week, the seed germination was observed. The germination rate was determined by the seeds that germinate,

$$
G P(\%)=\frac{\text { The number of seeds germinated }}{\text { The number of seeds tested }} \times 100 \%
$$

marked as by the appearance of radicles. The germination percentage (GP) was calculated by the formula (Wawo, 2008) as follows:

The height of the stem $(\mathrm{cm})$ was measured on a weekly basis. Plants were harvested when they were five weeks old, to measure root length $(\mathrm{cm})$, total fresh weight $(\mathrm{g})$, total dry weight $(\mathrm{g})$ and canopy ratios.

\section{Analysis of Chlorophyll and proline content}

Total chlorophyll content was measured using spectrophotometric method at $646 \mathrm{~nm}$ and $663 \mathrm{~nm}$ wavelength (Harborne, 1998). Chlorophyll was extracted in acetone $80 \%$. Meanwhile, leaf proline content was measured using a spectrophotometricaly method (Bates, 1973) with pure proline as standard. To prepare proline extract, about $0.5 \mathrm{~g}$ leaves was ground in 10 $\mathrm{mL}$ sulphosalicylic acid 3\%. Filtrate was added with $2 \mathrm{~mL}$ acetic acid and $2 \mathrm{~mL}$ ninhydrine acid. Sample solution was then extracted with $4 \mathrm{~mL}$ toluene and homogenized for 20s. Supernatant absorbance was then measured spectrophothometicaly at wavelength of $520 \mathrm{~nm}$. 


\section{Anatomical slides preparation}

The fourth leaf from the bud was sliced across the paraffin cuffing method (GTAC, 2016). The anatomical structure of the leaf is described, then measured by thickness of the mesophyll tissue $(\mu \mathrm{m})$, the thickness of the upper epidermal layer $(\mu \mathrm{m})$, the thickness of the lower epidermal layer $(\mu \mathrm{m})$, the distance between the vascular bundle sheath $(\mu \mathrm{m})$, and the Kranz anatomy diameter $(\mu \mathrm{m})$.

The calculation of stomatal density was performed on leaf impression slide. Clear nail polish was applied to the abaxial leaf and left it to dry. The clear sticky tape was placed on top of dried nail polish, removed with tweezers, placed on top of an object glass, dropped by water and covered by a glass cover. The field diameter of microscope view was measured using a micrometer to determine the area of view. The density of stomata (stomata per $\mathrm{mm}^{2}$ ) was identified at $10 \times 40$ microscope magnification. The length of stomata $(\mu \mathrm{m})$ and stomata width $(\mu \mathrm{m})$ was also measured.

\section{Data analysis}

Quantitative data were analyzed using t-test, ANOVA, and followed by DMRT test $\alpha=5 \%$.

\section{RESULT AND DISCUSSION}

\section{Germination and root length}

The duration of priming with salicylic acid showed different results between the $0 \%$ and $3 \%$ salinity treatment (Table 1). At $24 \mathrm{~h}$ priming yielded the lowest percentage of germination with $70 \%$, and $60 \%$ of $0 \%$ and $3 \%$ salinity respectively. These results indicate that the 24-h priming duration with salicylic acid may be phytotoxic in sweet corn by decreasing the percentage of germination. Salicylic acid in excess doses may inhibit the expression of alpha-amylase in aleurone cells, an enzyme for food reserves (starch) degradation in seeds that begin to germinate (Xie et al., 2007).

A priming treatment for 12 and $18 \mathrm{~h}$ at $3 \%$ salinity can maintain a normal germination percentage (as in $0 \mathrm{~h}$ and $0 \% \mathrm{NaCl}$ treatment), while $24 \mathrm{~h}$ decreased it. These results indicate that inhibition of germination on sweet corn can be prevented by a priming treatment using salicylic acid $(2 \mathrm{mM})$ with a duration of $12 \mathrm{~h}$ or $18 \mathrm{~h}$. Similar results was shown in cucumber (Rehman et al., 2011) that the administration of salicylic acid may increase the percentage of germination. During seed priming, supply water to seed is controlled, so that the seed moisture at a level below needed for real germination. This level is enough to start many physiological proccesses related to early germination but prevent the seed to full germination (Jisha et al., 2013; Paparella et al., 2015).

Salinity is known to cause two main effects in plants, namely osmotic stress and phytotoxic ions (Djukri, 2009). Plants are generally able to absorb water and minerals under normal conditions due to the osmotic pressure in the cells is higher than the osmotic pressure of the soil. When subjected to salinity treatment, the osmotic pressure on the soil becomes higher than that of the plant cell. This causes the ability of plants to absorb water was disturbed (Boudsocq and Laurière, 2005). In germinated seeds, water has an important role to stimulate the activation of hydrolytic enzymes that play a role in degrading food reserves. If the ability of water absorption in seeds is disrupted by salinity treatment, then the activation of the enzyme for germination will also be inhibited. This will certainly have a negative impact on the percentage of seed germination. Priming salicylic acid $2 \mathrm{mM}$ with a duration of $12 \mathrm{~h}$ or $18 \mathrm{~h}$ can reduce the negative impacts above (Table 1).

Table 1 also shows that priming duration has no

Table 1. The effect of priming duration with salicylic acid on germination percentage $(\%)$ and root length $(\mathrm{cm})$ on sweet corn seedlings grown under different salinity conditions

\begin{tabular}{|c|c|c|c|c|}
\hline \multirow{3}{*}{ Salinity } & \multicolumn{4}{|c|}{ Priming duration (h) } \\
\hline & 0 & 12 & 18 & 24 \\
\hline & \multicolumn{4}{|c|}{ Germination percentage $(\%)$} \\
\hline $0 \%$ & $90.00 \pm 6.13^{\mathrm{aA}}$ & $93.30 \pm 6.13^{\mathrm{aA}}$ & $96.60 \pm 5.46 \mathrm{aA}$ & $70.00 \pm 3.94^{\mathrm{bA}}$ \\
\hline \multirow[t]{2}{*}{$3 \%$} & $66.65 \pm 3.78^{\mathrm{bB}}$ & $90.00 \pm 5.10^{\mathrm{aA}}$ & $93.32 \pm 5.13^{\mathrm{aA}}$ & $60.00 \pm 4.12^{\mathrm{bA}}$ \\
\hline & \multicolumn{4}{|c|}{ Root length $(\mathrm{cm})$} \\
\hline$\overline{0 \%}$ & $31.30 \pm 5.16^{\mathrm{aA}}$ & $29.62 \pm 4.62^{\mathrm{aA}}$ & $31.73 \pm 1.31^{\mathrm{aA}}$ & $29.30 \pm 8.15^{\mathrm{aA}}$ \\
\hline $3 \%$ & $20.50 \pm 3.28^{\mathrm{bB}}$ & $29.10 \pm 3.50^{\mathrm{aA}}$ & $28.80 \pm 1.71^{\mathrm{aA}}$ & $26.53 \pm 3.68^{\mathrm{aA}}$ \\
\hline
\end{tabular}

Remarks: The number followed by the lowercase letter on the same row was not significantly different according to the DMRT test at $\alpha=5 \%$. The numbers followed by the same capital letters in the column was not significantly different according to the t test at $\alpha=5 \%$. 


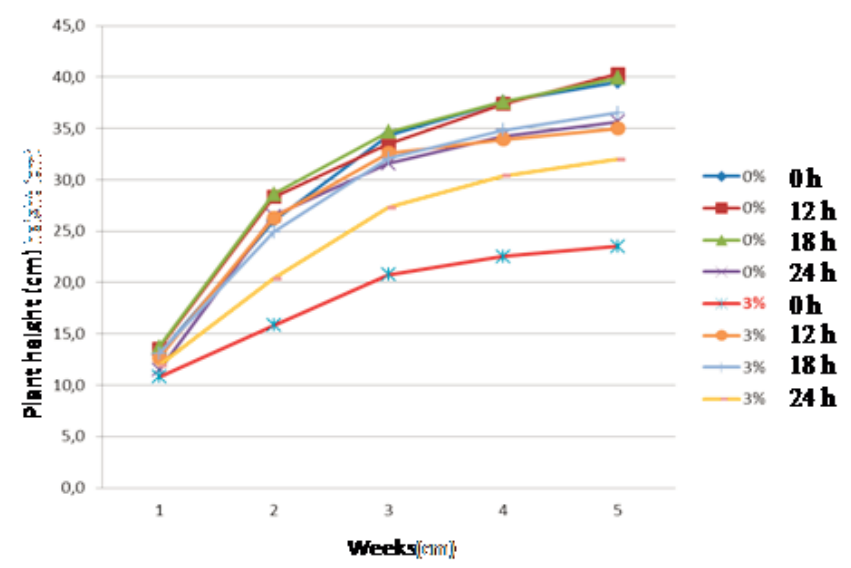

Figure 1. The effect of priming duration with salicylic acid on the plant height of sweet corn seedlings on different salinity

significant effect on root length of sweet corn seedlings at $0 \%$ salinity condition. However, plants with 3\% salinity without priming treatment had shorter roots than priming treatments of $12 \mathrm{~h}, 18 \mathrm{~h}$ and $24 \mathrm{~h}$. The $3 \%$ salinity treatment without priming inhibits root elongation of sweet corn seedlings, which was similar on Crotalaria juncea L. (Nugraheni et al., 2003), meanwhile, priming treatment of 12 , 18 and $24 \mathrm{~h}$ tends to recover the elongation of root.

In addition to inhibiting root growth, salinity was also shown to inhibit the growth of sweet corn stem. From Figure 1, it was seen that the 3\% salinity without priming yielded the shortest stem. This also occured in soybean (Kasanah and Maryani, 2017) and in maize under $120 \mathrm{mM} \mathrm{NaCl}$ (Agami, 2013) which the shoot length was back to normal growth as control when seeds were previously primed with $0.1 \mathrm{mM}$ salicylic acid. High salt concentration around the roots increases to a threshold level making it harder for the roots to extract water, the rate of shoot growth falls considerably (Batool et al., 2014). The above negative effects can be minimized by salicylic acid, where under 3\% salinity, all priming treatments resulted in higher plants stems compared to that without priming (Figure 1). Salicylic acid is known to play an important role in inhibiting the effects of ionic toxicity due to its ability to compete with $\mathrm{Na}+$ and $\mathrm{Cl}$ - ions at membrane transport levels (Gunes et al., 2005).

\section{Fresh and dry weight}

At $0 \%$ salinity, there was no significant difference on fresh and dry weights between treatments of priming duration (Table 2). In contrast, when $3 \%$ salinity was applied, there was a decrease in fresh and dry weight compared to control $(0 \mathrm{~h}$ priming and $0 \%$ priming duration) in all treatments, except for $18 \mathrm{~h}$ on fresh weight. Priming treatment with salicylic acid for $12 \mathrm{~h}, 18 \mathrm{~h}$ and $24 \mathrm{~h}$ increased fresh and dry weight of seedlings at $3 \%$ salinity treatment compared with control $(0 \mathrm{~h})$.

Salinity treatment decreased fresh and dry weight in Ceriops tagal(Ramayani et al., 2012) and maize (Agami, 2013) due to $\mathrm{Na}+$ and $\mathrm{Cl}$ - ions absorbed into the tissues inhibit metabolism and growth. Reduced

Table 2. The effect of priming duration with salicylic acid on fresh and dry weight (g) on sweet corn seedlings grown under different salinity conditions

\begin{tabular}{|c|c|c|c|c|}
\hline \multirow{3}{*}{ Salinity } & \multicolumn{4}{|c|}{ Priming duration (h) } \\
\hline & 0 & 12 & 18 & 24 \\
\hline & \multicolumn{4}{|c|}{ Fresh weight (g) } \\
\hline $0 \%$ & $4.24 \pm 0.01^{\mathrm{aA}}$ & $4.21 \pm 0.08^{\mathrm{aA}}$ & $4.26 \pm 0.23^{\mathrm{aA}}$ & $4.16 \pm 0.14^{\mathrm{aA}}$ \\
\hline \multirow[t]{2}{*}{$3 \%$} & $2.80 \pm 0.08^{\mathrm{cB}}$ & $3.23 \pm 0.44^{\mathrm{bB}}$ & $4.27 \pm 0.14^{\mathrm{aA}}$ & $3.18 \pm 0.06^{\mathrm{bB}}$ \\
\hline & \multicolumn{4}{|c|}{ Dry weight (g) } \\
\hline $0 \%$ & $0.71 \pm 0.09^{\mathrm{aA}}$ & $0.74 \pm 0.07^{\mathrm{aA}}$ & $0.72 \pm 0.05^{\mathrm{aA}}$ & $0.68 \pm 0.05^{\mathrm{aA}}$ \\
\hline $3 \%$ & $0.34 \pm 0.03^{\mathrm{bB}}$ & $0.42 \pm 0.10^{\mathrm{aB}}$ & $0.46 \pm 0.05^{\mathrm{aB}}$ & $0.39 \pm 0.02^{\mathrm{aB}}$ \\
\hline
\end{tabular}

Remarks: The number followed by the lowercase letter on the same row was not significantly different according to the DMRT test at $\alpha=5 \%$. The numbers followed by the same capital letters in the column was not significantly different according to the $\mathrm{t}$ test at $\alpha=5 \%$. 
Table 3. The effect of priming duration with salicylic acid on total chlorophyll and leaf proline content on sweet corn seedlings grown under different salinity conditions

\begin{tabular}{|c|c|c|c|c|}
\hline \multirow{3}{*}{ Salinity } & \multicolumn{4}{|c|}{ Priming duration (h) } \\
\hline & 0 & 12 & 18 & 24 \\
\hline & \multicolumn{4}{|c|}{ Total chlorophyll (mg/L) } \\
\hline $0 \%$ & $6.79 \pm 0.09^{\mathrm{dA}}$ & $11.08 \pm 0.03^{\mathrm{aA}}$ & $9.85 \pm 0.06^{\mathrm{bA}}$ & $9.42 \pm 0.75^{\mathrm{cA}}$ \\
\hline \multirow[t]{2}{*}{$3 \%$} & $3.33 \pm 0.11^{\mathrm{dB}}$ & $12.87 \pm 0.07^{\mathrm{aA}}$ & $8.94 \pm 0.09^{\mathrm{cA}}$ & $10.03 \pm 0.06^{\mathrm{bA}}$ \\
\hline & \multicolumn{4}{|c|}{ Proline content in leaves $\left(\mu \mathrm{mol} \mathrm{g}^{-1}\right.$ fresh weight $)$} \\
\hline $0 \%$ & $0.64 \pm 0.02^{\mathrm{cB}}$ & $0.77 \pm 0.05^{\mathrm{bB}}$ & $1.14 \pm 0.10^{\mathrm{aA}}$ & $1.17 \pm 0.03^{\mathrm{aA}}$ \\
\hline $3 \%$ & $1.08 \pm 0.06^{\mathrm{bA}}$ & $1.11 \pm 0.06^{\mathrm{bA}}$ & $1.28 \pm 0.05^{\mathrm{aA}}$ & $1.30 \pm 0.08^{\mathrm{aA}}$ \\
\hline
\end{tabular}

moisture levels in plant tissues due to salt stress will be followed by a decrease in stomatal closure, cell turgor, thus inhibiting the rate of photosynthesis and the low amount of assimilate produced (Pangaribuan, 2001).

High salinity can cause hyperosmotic pressure in plants (Boudsocq and Laurière, 2005). This results in reduced turgor pressure and loss of water from the tissues. Excess $\mathrm{Na}+$ ion in the plant tissue will increase the level of membrane leakage (Anthraper and Dubois, 2003). Priming treatment with salicylic acid for $12 \mathrm{~h}, 18 \mathrm{~h}$ and $24 \mathrm{~h}$ were able to raise fresh and dry weight of sweet corn seedlings when received 3\% $\mathrm{NaCl}$ treatment compared to control. Salicylic acid in a dose of $0.1 \mathrm{mM}$ was able to increase the activity of antioxidant enzymes such as catalase and peroxidase that reduce the effects of oxidative stress due to stress (Agami, 2013). In this study application of salicylic acid, as seed soaking in absence or presence of $\mathrm{NaCl}$ stress stimulated the growth compared to the control. These positive results were obtained as a result of salicylic acid overcoming the harmful effects of $\mathrm{NaCl}$ stress by the induction photosynthetic pigments and proline content (Table $3)$ which consequently delayed leaf senescence which is induced by salt stress.

\section{Total chlorophyll content and proline}

At $0 \%$ and $3 \%$ salinity, the priming duration of $12 \mathrm{~h}$ yields the highest total chlorophyll compared with other priming durations (Table 3). Salinity 3\% significantly reduced chlorophyll content, when applied without priming. Salinity suppresses the enzyme responsible for the chlorophyll synthesis process (Munns andTester, 2008). In addition, high salinity will reduce the ability of plants to absorb nutrient minerals such as magnesium $(\mathrm{Mg})$ required by plants for photosynthetic pigment biosynthesis such as chlorophyll (Anthraper and Dubois, 2003). In this study, the reduction of chlorophyll content was recovered by salicylic acid application, in all priming durations. Under $0 \%$ salinity condition, salicylic acid significantly increased chlorophyll content. Salicylic acid in low doses can stimulate $\mathrm{CO} 2$ assimilation in Brassica juncea seedlings (Fariduddin, 2003), Rubisco activity in corn (Khodary, 2004), antioxidant enzyme activity in corn (Agami, 2013) and in Torreya grandis (Li et al., 2014) followed by increased chlorophyll content. In excessive doses, salicylic acid increased in ethylene productionleading to a decrease in chlorophyll in plants (Arfan et al., 2007).

On a priming duration of $0 \mathrm{~h}$, a $3 \%$ salinity treatment increased the accumulation of proline in leaves (Table 2). Priming treatment with salicylic acid 2 $\mathrm{mM}$ can increase the level of proline under normal conditions or $3 \%$ salinity treatment. The longer the duration of priming, the accumulation of proline increases. In general, in the priming treatment, in the $3 \% \mathrm{NaCl}$ condition, the proline level was higher than the $0 \%$ salinity treatment, although significant results were only in the priming duration of $0 \mathrm{~h}$ and $12 \mathrm{~h}$. In the treatment without priming, the proline level increased significantly from $0.64 \mu \mathrm{mol} \mathrm{g}^{-1}$ to $1.08 \mu \mathrm{molg}^{-1}$ under $3 \%$ salinity treatment. In the 18 $\mathrm{h}$ and $24 \mathrm{~h}$ priming treatments, although there was an increase, there was no significant difference between the proline level when conditions were recorded and the salinity was not recorded.

The same results were reported by Khan et al. (2013) on wheat (Triticum aestivum L.) treated with salicylic acid $0.5 \mathrm{mM}$ and in Crotalaria juncea $\mathrm{L}$. (Djukri, 2009). The accumulation of proline in stressful plants will increase as salicylic acid is known to interact with proline metabolism (Khan et al., 2013). 
Table 4. The effect of priming duration with salicylic acid on leaf anatomy and stomatal density on sweet corn seedlings grown under different salinity conditions

\begin{tabular}{|c|c|c|c|c|}
\hline \multirow{2}{*}{ Salinity } & \multicolumn{4}{|c|}{ Priming duration $(\mathrm{h})$} \\
\hline & 0 & 12 & 18 & 24 \\
\hline & \multicolumn{4}{|c|}{ Adaxial Epidermall cell thickness $(\mu \mathrm{m})$} \\
\hline $0 \%$ & $19.7 \pm 1.68^{\mathrm{aA}}$ & $19.7 \pm 1.68^{\mathrm{aA}}$ & $19.7 \pm 1.68^{\mathrm{aA}}$ & $19.7 \pm 1.68^{\mathrm{aA}}$ \\
\hline \multirow[t]{2}{*}{$3 \%$} & $16.89 \pm 0.78^{\mathrm{bB}}$ & $16.89 \pm 0.78^{\mathrm{bB}}$ & $16.89 \pm 0.78^{\mathrm{bB}}$ & $16.89 \pm 0.78^{\mathrm{bB}}$ \\
\hline & \multicolumn{4}{|c|}{ Abaxial Epidermall cell thickness $(\mu \mathrm{m})$} \\
\hline $0 \%$ & $17.85 \pm 1.07^{\mathrm{aA}}$ & $17.67 \pm 1.33^{\mathrm{aA}}$ & $18.11 \pm 1.31^{\mathrm{aA}}$ & $17.52 \pm 1.22^{\mathrm{aA}}$ \\
\hline \multirow[t]{2}{*}{$3 \%$} & $15.67 \pm 0.71^{\mathrm{bB}}$ & $17.85 \pm 1.07^{\mathrm{aA}}$ & $17.68 \pm 0.89^{\mathrm{aA}}$ & $17.96 \pm 1.09^{\mathrm{aA}}$ \\
\hline & \multicolumn{4}{|c|}{ Mesophyll cell thickness $(\mu \mathrm{m})$} \\
\hline $0 \%$ & $68.78 \pm 4.65^{\mathrm{aA}}$ & $69.36 \pm 5.69^{\mathrm{aA}}$ & $67.06 \pm 4.27^{\mathrm{aA}}$ & $66.89 \pm 7.13^{\mathrm{aA}}$ \\
\hline \multirow[t]{2}{*}{$3 \%$} & $52.16 \pm 6.64^{\mathrm{bB}}$ & $67.39 \pm 4.94^{\mathrm{aA}}$ & $68.42 \pm 4.71^{\mathrm{aA}}$ & $66.36 \pm 6.44^{\mathrm{aA}}$ \\
\hline & \multicolumn{4}{|c|}{ Leaf thickness $(\mu \mathrm{m})$} \\
\hline $0 \%$ & $106.33 \pm 4.84^{\mathrm{aA}}$ & $107.53 \pm 5.68^{\mathrm{aA}}$ & $106.18 \pm 4.45^{\mathrm{aA}}$ & $104.48 \pm 6.28^{\mathrm{aA}}$ \\
\hline \multirow[t]{2}{*}{$3 \%$} & $84.72 \pm 7.31^{\mathrm{bB}}$ & $104.88 \pm 6.23^{\mathrm{aA}}$ & $105.43 \pm 4.70^{\mathrm{aA}}$ & $103.31 \pm 6.31^{\mathrm{aA}}$ \\
\hline & \multicolumn{4}{|c|}{ Distance between vascular sheets $(\mu \mathrm{m})$} \\
\hline $0 \%$ & $40.61 \pm 3.05^{\mathrm{aA}}$ & $43.5 \pm 4.02^{\mathrm{aA}}$ & $43.24 \pm 4.59^{\mathrm{aA}}$ & $43.65 \pm 5.13^{\mathrm{aA}}$ \\
\hline \multirow[t]{2}{*}{$3 \%$} & $41.65 \pm 3.64^{\mathrm{aA}}$ & $42.25 \pm 4.86^{\mathrm{aA}}$ & $42.19 \pm 4.25^{\mathrm{aA}}$ & $43.37 \pm 4.82^{\mathrm{aA}}$ \\
\hline & \multicolumn{4}{|c|}{ Diameter of Kranz anatomy $(\mu \mathrm{m})$} \\
\hline $0 \%$ & $56.32 \pm 4.97^{\mathrm{aA}}$ & $58.83 \pm 6.39^{\mathrm{aA}}$ & $56.14 \pm 6.28^{\mathrm{aA}}$ & $56.59 \pm 9.34^{\mathrm{aA}}$ \\
\hline \multirow[t]{2}{*}{$3 \%$} & $52.87 \pm 5.22^{\mathrm{bA}}$ & $57.31 \pm 4.86^{\mathrm{abA}}$ & $58.76 \pm 4.98^{\mathrm{aA}}$ & $55.89 \pm 5.36^{\mathrm{abA}}$ \\
\hline & \multicolumn{4}{|c|}{ Stomata length $(\mu \mathrm{m})$} \\
\hline $0 \%$ & $26.62 \pm 1.33^{\mathrm{aA}}$ & $25.87 \pm 0.88^{\mathrm{aA}}$ & $26.41 \pm 1.37^{\mathrm{aA}}$ & $25.78 \pm 1.40^{\mathrm{aA}}$ \\
\hline \multirow[t]{2}{*}{$3 \%$} & $25.36 \pm 0.79^{\mathrm{aA}}$ & $26.84 \pm 1.40^{\mathrm{aA}}$ & $26.12 \pm 1.69^{\mathrm{aA}}$ & $26.47 \pm 1.56^{\mathrm{aA}}$ \\
\hline & \multicolumn{4}{|c|}{ Stomata width $(\mu \mathrm{m})$} \\
\hline $0 \%$ & $20.23 \pm 1.13^{\mathrm{aA}}$ & $20.26 \pm 1.55^{\mathrm{aA}}$ & $20.17 \pm 1.41^{\mathrm{aA}}$ & $20.34 \pm 1.47^{\mathrm{aA}}$ \\
\hline \multirow[t]{2}{*}{$3 \%$} & $18.37 \pm 0.66^{\mathrm{bB}}$ & $20.13 \pm 1.01^{\mathrm{aA}}$ & $20.64 \pm 1.61^{\mathrm{aA}}$ & $19.98 \pm 0.94^{\mathrm{abA}}$ \\
\hline & \multicolumn{4}{|c|}{ Stomatal density (number of stomata per $\mathrm{mm}^{2}$ ) } \\
\hline $0 \%$ & $45.88 \pm 5.17^{\mathrm{aA}}$ & $44.00 \pm 5.13^{\mathrm{aA}}$ & $45.25 \pm 7.73^{\mathrm{aA}}$ & $43.99 \pm 5.93^{\mathrm{aA}}$ \\
\hline $3 \%$ & $38.34 \pm 4.64^{\mathrm{bB}}$ & $44.62 \pm 6.92^{\mathrm{aA}}$ & $43.37 \pm 4.64^{\mathrm{abA}}$ & $44.52 \pm 6.92^{\mathrm{aA}}$ \\
\hline
\end{tabular}

Remarks: The number followed by the lowercase letter on the same row was not significantly different according to the DMRT test at $\alpha=5 \%$. The numbers followed by the same capital letters in the column was not significantly different according to the $\mathrm{t}$ test at $\alpha=5 \%$.

\section{Leaf anatomical structure}

The duration of priming with salicylic acid did not affect all anatomical characters of sweet corn seedling leaves at $0 \%$ salinity condition (Table 4$)$. In contrast, the $3 \%$ salinity treatment showed the increasing thickness of the upper and lower epidermal, mesophyll, leaves and Kranz anatomy as well as stomata width at the priming, but the vascular intercellular distance and stomatal length did not differ significantly between all treatments of priming duration. Similar results were also reported in maize plants treated with salinity and salicylic acid application through roots (Carcamo et al., 2012). Salinity negatively affects the anatomical structure of maize leaves so that the size is smaller, but the application of salicylic acid in the growing medium will prevent the change of mesophyll, epidermal, anatomic, and xylem tissue.

Anatomical changes are one of the responses of plants when under stress to maintain water efficiency and carbon uptake (Hernandez, 2001). Figure 2 shows that sweet corn seedlings with 3\% salinity treatment without priming (E) have reduced leaf thickness, and have bulliform cells and stomata of smaller size than other treatments. This reduction is not caused by a reduction in the number of mesophyll layers or epidermis, but rather because the cell size changes from the tissue become smaller (Table 4). The decrease in mesophyll thickness of the $\mathrm{NaCl}$ stressed leaves may arise from a reduction in mesophyll cells and the decrease in lamina thickness can also 

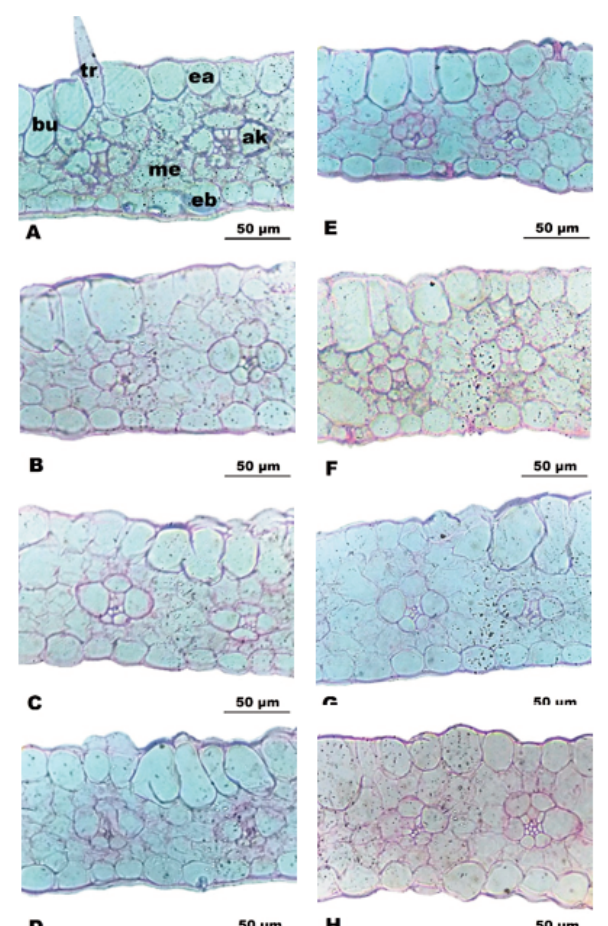

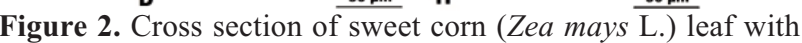
salinity treatment $0 \%$ (left) and 3\% (right, and duration priming $0 \mathrm{~h}(\mathrm{~A}, \mathrm{E}), 12 \mathrm{~h}(\mathrm{~B}, \mathrm{~F}), 18 \mathrm{~h}(\mathrm{C}, \mathrm{G})$ and $24 \mathrm{~h}$ $(D, H)$. ea = adaxial epidermis; $\mathrm{eb}=$ abaxial epidermis; $\mathrm{me}=$ mesophyll; $\mathrm{ak}=\mathrm{Kranz}$ anatomy; $\mathrm{bu}=$ bulliform cells; $\operatorname{tr}=$ trichome

be related to smaller volumes of mesophyll cells in salinity stressed leaves (Agami, 2013).The reduced leaf thickness indicates that the growth of leaf cells is hampered by salinity treatment. Cell growth itself is closely related to the osmotic balance in tissues. If the osmotic balance is disrupted, the rate of cell division and elongation will also decrease (Bastias et al., 2004).

The inhibition of leaf growth may also be associated with the toxicity of $\mathrm{Na}^{+}$and $\mathrm{Cl}^{-}$ions that are accumulated by plants to increase the osmotic value of the tissues (Munns and Tester, 2008). Salicylic acid is known to have an important role to inhibit the removal of certain ions such as $\mathrm{Na}+$ and $\mathrm{Cl}-$ at the transport level of the membrane (Gunes et al., 2005).

\section{Stomatal density}

Duration of priming with salicylic acid had no effect on stomatal density on sweet corn seedlings at $0 \%$ salinity (Table 4). In contrast, in the 3\% salinity treatment, there was a significant difference between stomata density of sweet corn seedlings treated without priming with priming treatment of $12 \mathrm{~h}$ and $24 \mathrm{~h}$. At different salinity levels, the density of stomata only differed significantly in treatment without priming. Meanwhile, in the treatment of priming duration 12 $\mathrm{h}, 18 \mathrm{~h}$ and $24 \mathrm{~h}$, salinity level did not seem to have real effect. Similar results were found in tomato plants where stomata density was reduced after was given salt stress (Romero-Aranda, 2001). These results may be related to the disruption of growth of stomatal cells in the leaves due to osmotic disturbances as well as toxicity of $\mathrm{Na}+$ and $\mathrm{Cl}-$ ions (Munns and Tester, 2008). Negative effects can be prevented by the administration of salicylic acid that is able to reduce ionic phytotoxicity due to the excessive entry of $\mathrm{Na}+$ and $\mathrm{Cl}+$ ions in plant tissues (Gunes et al., 2005).

\section{CONCLUSIONS}

Without priming, salinity $3 \%$ significantly decreased the percentage of germination, root length, plant height, fresh and dry weight, chlorophyll content, the thickness of adaxial epidermis, mesophyll and leaf, stomatal density and width, but increased proline content. Priming seeds with salicylic acid for 12 and $18 \mathrm{~h}$, significantly maintained the germination percentage, while $24 \mathrm{~h}$ priming tended to inhibit germination both in $0 \%$ and $3 \%$ salinity. Priming with salicylic acid for 12,18 or $24 \mathrm{~h}$ recovered the root and stem growth, increased fresh and dry weight, chlorophyll and proline content as well as maintained the leaf anatomical structure from the 3 $\% \mathrm{NaCl}$ effect. The optimal duration of priming with salicylic acid on sweet corn (Zea mays L.) with salinity 
treatment was $18 \mathrm{~h}$.

\section{REFERENCES}

Adillah, A. 2016.Pertumbuhan dan Produksi Beberapa Aksesi Hotong (Setaria italica (L.)Beauv.)pada Cekaman Salinitas. Skripsi.IPB. Bogor. pp. 56.Available at http:// repository.ipb.ac.id/ jspui/ bitstream/123456789/79559/1/A16aad.pdf.

Agami, R.A. 2013. Alleviating the adverse effects of $\mathrm{NaCl}$ stress in maize seedlings by pretreating seeds with salicylic acid and 24-epibrassinolide. South African Journal of Botany88, pp. 171177.Available at https: //www.sciencedirect. com/science/article/pii/S0254629913003220.

Anthraper, A., and J. D. Dubois. 2003. The effect of $\mathrm{NaCl}$ on growth, $\mathrm{N} 2$ fixation and percentage total nitrogen in Leucaenaleucacephala var K-8. American Journal of Botany, 90: 683-692. Available at https: // www. ncbi. nlm.nih. gov/ pubmed/ 2165916.

Arfan, M., H. R. Athar, M. Ashraf. 2007. Does exogenous application of salicylic acid through the rooting medium modulate growth and photosynthetic capacity in two differently adapted spring wheat cultivars under salt stress? Journal of Plant Physiology, 164, pp.685-694. Available at https://www.ncbi.nlm.nih.gov/pubmed/16884 826.

Arif, M., M.T. Jan, N. U. Khan, A. Khan, M. J. Khan, I. Munir. 2010. Effect of seed priming on growth parameters of soybean.Pakistan Journal of Botany, 42(2), pp. 2803-2812.

Bastias, E., M. B. Gonzales-Moro, C.GonzalesMunia. 2004.Zea mays L. amylacea from the Lluta Valley (Africa-Chile) tolerates salinity stress when high levels of boron are available. Plant and Soil, 267, pp. 73-84. Available at https://link.springer.com/content/pdf/10.1007/ s11104-005-4292-y.pdf.

Bates, L.S., R. P. Waldren, I. D. Tare. 1973. Rapid determination of free proline for water-stress studies. Plant, Soil, 39, pp. 205-207. Available at https://link.springer.com/article/10.1007/BF00 018060 .

Batool N., A. Shahzad, N. Ilyas and T. Noor. 2014. Plant and salt stress. International Journal of Agriculture Crop Science, 7 (9), pp. 582-589. Available at ijagcs.com/wp-content/uploads/2014/06/582589.pd.

Boudsocq, M. and C. Laurière. 2005. Osmotic Signaling in Plants. Multiple Pathways Mediated by Emerging Kinase Families .Plant Physiology, 138 (3), pp. 1185-1194. Available at https://www.ncbi.nlm.nih.gov/pmc/articles/P MC1176393/.
Carcamo, H.J., R. M. Bustos, F. E. Fernandez, E. I. Bastias. 2012.Mitigating effect of salicylic acid in the anatomy of the leaf of Zea mays L. Iluteno ecotype from the Lluta Valley (Arica-Chile) under NaCl.Idlesia, 30(3), pp. 55-63. Available at www. scielo.cl/ pdf/ idesia/ v30n3/ art07.pdf.

Dachlan, A., N. Kasim, and A. K. Sari. 2013.Uji ketahanan salinitas beberapa varietas jagung (Zea mays L.) dengan menggunakan agen seleksi NaCl. Biogenesis, 1(1), pp. 9-17. Available at journal. uin- alauddin. ac.id/ index.php/ biogenesis/article/ view/ 442.

Djukri. 2009. Cekaman Salinitas terhadap Pertumbuhan Tanaman. Prosiding Seminar Nasional Penelitian, Pendidikan dan Penerapan MIPA, Fakultas MIPA, Universitas Negeri Yogyakarta, Yogyakarta. pp. 49-55. Available at eprints.uny.ac.id/12120/1/Bio_Djukri1\%2C\% 20UNY.pdf.

Farahmandfar, E., M. B. Shirvan, S. A. Sooran, B. Hoseinzadeh. 2013. Effect of seed priming on morphological and physiological paramaters of fenugreek seedlings under salt stress. IJACS Journal, 5(8), pp. 811-815. Available at https://www.researchgate.net/.../292258491 Effect_of_seed_priming_on_morphologica.

Fariduddin, Q., S. Hayat, and A. Ahmad. 2003. Salicylic acid influences net photosynthetic rate, carboxylation efficiency, nitrate reductase activity, and seed yield in Brassicajuncea. Photosynthetica, 41, pp. 281-283. Available at https:// link. springer. com/ article/ 10.1023/ B: PHOT. 0000011962. 05991.6c.

GTAC, 2016. Measuring Stomatal Density (Leaf Impression Method). Gene Technology Access Centre. Victoria. pp.1-4. Available at https://www.gtac.edu.au/wp-content/uploads/.../StomatalDensity_LabPreparation.p df.

Gunes, A., A. Inal, M. Alpaslan, F. Eraslan, E. Guneri, and N. Cicek. 2005. Salicylic acid changes on some physiological parameters symptomatic for oxidative stress and mineral nutrition in maize (Zea mays L.) grown under salinity. Journal of Plant Physiology, 164, pp. 728-736. Available at https://www.sciencedirect. com/science/article/pii/S0176161706000496.

Harborne, J.B. 1998. Phytochemical Methods: A Guide to Modern Techniques of Plant Analysis 3rd Edition. Chapman \& Hall. London. pp. 227-229.

Herlina, N.F.N. \& S. A. Aziz. 2016.Peningkatan viabilitas benih jintan hitam (Nigellasativa) dengan hidropriming dan pemberian asam giberelat.Buletin Penelitian Tanaman Rempah 
dan Obat, 27(2), pp. 129-136. Available at ejurnal.litbang.pertanian.go.id/index.php/bultro/ar ticle/view/3920.

Hernandez, J.A., M. A. Ferrer, A. Jimenez, A. RosBarcelo, and F. Sevilla. 2001. Antioxidant system and $\mathrm{O} 2-/ \mathrm{H} 2 \mathrm{O} 2$ production in the apoplast of Pisum sativum L. leaves: its relation with $\mathrm{NaCl}$-induced necrotic lesions in minor veins. Plant Physiology, 127, pp. 817-834. Available at https://www. ncbi.nlm.nih. gov/ pmc/ articles /PMC129254.

Imran, M. Nutrient Seed Priming Improves Abiotic Stress Tolerance in Zea mays L. and Glycine max L. 2012. (Dissertation).Institute of Crop Science, Nutritional Crop Physiology, University of Hohenheim. pp.46-55. Available at https: //opus.uni-hohenheim.de/volltexte/2014/ 947/pdf/Imran_Thesis.pdf.

Jayakannam, M., J. Bose, O. Babourina, Z. Rengel, and S. Shabala. 2013. Salicylic acid improves salinity tolerance in Arabidopsis by restoring membrane potential and preventing salt-induced $\mathrm{K}+$ loss via a GORK channel. Journal of Experimental Botany, 64(8), pp.55-68. Available at https: // www.ncbi. nlm.nih.gov/ pmc/ articles/ PMC3654417.

Jisha K. C., K. Vijayakumari, and J. T. Puthur. 2013. Seed priming for abiotic stress tolerance: An overview. Acta Physiologia Plantarum, 35(5), pp. 1381-1396. Available at https:// link. springer.com/ article/10.1007/s11738-0121186-5.

Kasanah, N., and Maryani. 2017. Roots anatomy and growth responses of soybean (Glycine max (L.)Merr.) 'Wilis" to $\mathrm{NaCl}$ stress. J. Trop. Biodiv. Biotech. 2, pp. 1-9. Available at https://link.springer.com/chapter/10.1007/978 -3-319-60363-6_20.

Khan, M.I.R., M. Fatma, T. S. Per, N. A. Anjum, N.A. Khan. 2013. Salicylic acid-induced abiotic stress tolerance and underlying mechanisms in plants. Frontiers in Plant Science, 6, pp. 462-497.Available at https: //www.ncbi.nlm. nih.gov/pubmed/26175738.

Khodary, S.E.A. 2004. Effect of salicylic acid on the growth, photosynthesis and carbohydrate metabolism in salt stressed maize plants. International Journal of Agriculture and Biology, 6, pp. 5-8. Available at citeseerx.ist.psu.edu/viewdoc/download?doi= 10.1.1.322.9285\&rep=rep1.

Li, T., Y. Hu, X. Du, H. Tang, C. Shen, J. Wu. 2014. Salicylic acid alleviates the adverse effects of salt stress in Torreya grandis cv. Merrillii seedlings by activating photosynthesis and enhancing antioxidant systems. PLoS ONE, 9(10),pp.e109492.doi:10.1371/journal. pone.0109492.

Mukhtar, K., I. Afzal, M. Qasim, S. M. A. Basra, and M. Shahid. 2013. Does priming promote germination and early stand establishment of french marigold (Tagetes patula L.) seeds by inducing physiological and biochemical changes? Acta Scientiarum Polonorum Hortorum Cultu, s 12(3):12-31. Available at http:// wydawnictwo.up. lublin.pl /acta/ hortorum cultus/2013/streszczenia2013 3/02 $\% 20$ Mukhtar\%20Qasim\%20Hort\%2012_3_ $\% 202013$.pdf.

Munns, R. \& M. Tester. 2008.Mechanisms of salinity tolerance.Annual Review of Plant Biology, 59, pp. 651-681.doi: 10.1146/ annurev. arplant.59.032607.092911

Nawaz, J., M. Hussain, A. Jabbar, G. A. Nadeem, M. Sajid, M. Subtain, I. Shabbir. 2013. Seed priming a technique.IJACS, 6(20), pp. 13731381. Available at https://pdfs.semantic scholar.org/10c5/260315229e9b27479706ab2 d06920d3df0d0.pdf.

Nugraheni, I., Solichatun, and E. Anggarwulan. 2003. Pertumbuhan dan akumulasi prolin tanaman orok-orok (Crotalaria juncea L.) pada salinitas $\mathrm{CaCl} 2$ berbeda.BioSMART, 5(2), pp. 98-101. Available at biosains. mipa.uns. ac.id/B/ B0502/B050206. pdf

Palungkun, R. \& B. Asiani. 2004. Sweet Corn-Baby Corn: Peluang Bisnis, Pembudidayaan dan Penanganan Pasca Panen. Penebar Swadaya. Jakarta. p.79. Available at digilib. usu.ac.id/.../ Sweet-corn- baby-corn-:-peluang-bisnis-pembud.

Pangaribuan, N. 2001.Hardening dalam Upaya Mengatasi Efek Toksik pada Tanaman Bayam (Amaranthus sp.).Jurnal Matematika, Sains dan Teknologi, (1), pp. 25-29.

Paparella S., S.S. Araújo, G. Rossi, M. Wijayasinghe, D. Carbonera, A. Balestrazzi. 2015. Seed priming: state of the art and new perspectives. Plant Cell Rep.34(8):1281-1293. doi: 10.1007/s00299-015-1784-y. Available at https://www.ncbi.nlm.nih.gov/pubmed/25812 837.

Ramayani, M. Basyuni, L. Agustina. 2012.Pengaruh salinitas terhadap pertumbuhan dan biomassa semai dan kandungan lipida pohon non-sekresi Ceriops tagal. Peronema Forestry Science Journal, 1(1), pp. 1-9. Available at https: // jurnal. usu.ac.id/ index.php/ PFSJ/article/ view/ 560.

Rehman, H., M. Farooq, S.M.A. Basra and I. Afzal, 2011. Hormonal priming with salicylic acid improves the emergence and early seedling 
growth in cucumber. J. Agric. Soc. Sci., 7, pp. 109-113.Available at http:// www. academia. edu/27169495/Hormonal Priming with Salycylic_Acid_Improves_the_Emergence_and_Earl y_Seedling_Growth_in_Cucumber.

Romero-Aranda, R., T. Soria, J. Cuartero. 2001.Tomato plant-water uptake and plant-water relationship under saline growth conditions. Plant Science, 160, pp. 265-272. Available .at https:// www. science direct. com/ science/ article/pii/S0168945200003885.

Ruzin SE. 1999. Plant microtechnique and microscopy. Oxford, New York: Oxford University Press.

Sedghi, M., A.B. Bahman, B. Javad. 2014. Physiological enhancement of medicinal pumpkin seeds (Cucurbita pepo var. styriaca) with different priming methods. Iranian Journal of Plant Physiology, 5(1), pp. 1209-1215. Available at www.sid.ir/En/Journal/ViewPaper.aspx?ID=5 18212.

Sudaryanto, T., R. Kustiari, H. P. Saliem. 2010.Analisis Sumber Daya Lahan Menuju Ketahanan Pangan Berkelanjutan. BPP Pertanian. Jakarta. pp.123.

Suwignyo, R.A., R. Hayati, and Mardiyanto. 2010. Toleransi tanaman jagung terhadap salinitas dengan perlakuan stress awal rendah. Jurnal Agrivor, 10(1), pp. 73-83. Available at http:// download. portal garuda. org/ article.php? article

$$
=29702 \& \mathrm{val}=2165 \text {. }
$$

Wawo, A.H. 2008. Study on seed germination and seedling growth models of sandalwood (Santalum album L.) of several mother seed trees in Belu Regency, East Nusa Tenggara. Biodiversitas, 9(2), pp. 117-122. Available at https:// smujo.id/ biodiv/article/view/393.

Xie, Z., Z. Zhang, S. Hanzlik, E. Cook, and Q. J. Shen. 2007. Salicylic acid inhibits gibberellininduced alpha-amylase expression and seed germination via a pathway involving an abscisic acid-inducible WRKY gene.Plant Molecular Biology, 64 (3), pp. 293-303. Available at https://www. ncbi.nlm.nih. gov/ pubmed/ 17390108.

Zadehbagheri, M. 2014. Salicylic acid priming in corn (Zea mays L. var. Sc.704) Reinforces $\mathrm{NaCl}$ tolerance at germination and the seedling growth stage.International Journal of Bioscience, 4(5), pp. 187-197. Available at https://www.cabdirect.org/cabdirect/abstract/2 0143125731.

Zahra, S., B. Amin, V. S. Ali, Y. Ali, and Y. Mehdi. 2010. The salicylic acid effect on the tomato (Lycopersicum esculentum Mill.) sugar, protein 